\title{
Effects of cadmium on hemolymph composition in the shore crab Carcinus maenas
}

\author{
Poul Bjerregaard \& Tone Vislie
}

Institute of Biology, Odense University, Campusvej 55, DK-5230 Odense M, Denmark

\begin{abstract}
Effects of cadmium exposure on regulation of osmolality and sodium, chloride, potassium, calcium, magnesium, and cadmium levels in the hemolymph of the shore crab Carcinus maenas (L.)

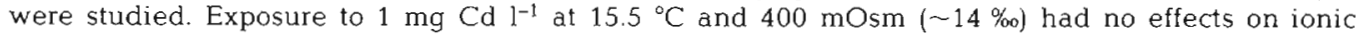
concentrations during $48 \mathrm{~d}$. Exposure to $\geq 4 \mathrm{mg} \mathrm{Cd} \mathrm{l}^{-1}$ augmented calcium levels in the hemolymph, while magnesium concentrations were reduced after prolonged exposure to 2 and $4 \mathrm{mg} \mathrm{Cd}^{-1}$. In some experiments exposure to $10 \mathrm{mg} \mathrm{Cd} \mathrm{l}^{-1}$ augmented $\mathrm{Na}^{+}, \mathrm{K}^{+}$, and $\mathrm{Cl}^{-}$concentrations and osmolality, but the effects were not consistent. Crabs exposed to $\leq 2 \mathrm{mg} \mathrm{Cd} \mathrm{l}^{-1}$ maintained cadmium levels in the hemolymph at or slightly below ambient cadmium concentrations, while cadmium levels in the hemolymph rose above ambient levels in crabs exposed to 4 to $10 \mathrm{mg} \mathrm{Cd}^{-1}$. Effects on calcium levels in the hemolymph coincided with increases in cadmium levels in the hemolymph. More than $95 \%$ of the cadmium in the hemolymph was bound to high molecular weight proteins and upon in vitro addition of cadmium to hemolymph samples free cadmium could not be detected before the cadmium concentration exceeded $16 \mu \mathrm{g} \mathrm{Cd} \mathrm{ml}^{-1}$.
\end{abstract}

\section{INTRODUCTION}

Cadmium contamination of the marine environment due to increased anthropogenic input is most likely to occur in coastal and estuarine areas. Organisms inhabiting these areas encounter wide variations in external salinities and ion concentrations. Reduction in salinity augments uptake rate and toxicity of cadmium in brachyuran crabs (O'Hara 1973a, b, Hutcheson 1974, Rosenberg \& Costlow 1976. Wright $1977 \mathrm{a}, \mathrm{b}$ ) and other marine organisms (reviewed by Coombs 1979).

Cadmium uptake and accumulation in the shore crab Carcinus maenas has been studied in great detail in recent years (Wright $1977 \mathrm{a}, \mathrm{b}, \mathrm{c}$, Jennings \& Rainbow 1979, Jennings et al. 1979, Rainbow \& Scott 1979, Wright \& Brewer 1979, Bjerregaard 1982, ChassardBouchaud 1982). Although the effect of reduced salinity on cadmium toxicity is well established (Coombs 1979), investigations of cadmium's effect on ion- and osmoregulation processes in $C$. maenas and other marine organisms are scarce.

At salinities below $33 \%$ Carcinus maenas normally maintains hemolymph osmolality and $\mathrm{Na}^{+}, \mathrm{Cl}^{-}, \mathrm{K}^{+}$, and $\mathrm{Ca}^{++}$levels above those of the ambient seawater (Webb 1940, Robertson 1960, Shaw 1961, Theede 1969, Greenaway 1976, Zanders 1980a), while $\mathrm{Mg}^{++}$concentrations are held substantially below ambient sea- water concentrations in 15 to $150 \%$ seawater (Lockwood \& Riegel 1969, Zanders 1980b). Thurberg et al. (1973) reported an augmenting effect of cadmium on total osmolality in the hemolymph of C. maenas, but the effect of cadmium on regulation of individual inorganic hemolymph ions has not been investigated.

Wright (1977a, b, c) and Wright \& Brewer (1979) observed that the cadmium concentration in the hemolymph of Carcinus maenas remains at a lower level than that of the surrounding medium, even if the latter is close to the background concentration or raised to $2.4 \mathrm{mg} \mathrm{Cd} \mathrm{l}^{-1}$. Wright \& Brewer (1979) suggest that the cadmium concentration of the hemolymph can be kept at a low level because cadmium after uptake via the gills is removed from the hemolymph by uptake in the hepatopancreas. Jennings et al. (1979) suggest that cadmium is transported in the hemolymph, bound to specific low molecular weight proteins with a high affinity for cadmium. Chassard-Bouchaud (1982) suggests that $C$. maenas detoxifies cadmium in the hepatopancreas by immobilizing the metal in mineral concretions. It is not known if $C$. maenas can regulate hemolymph cadmium levels at ambient cadmium concentrations above $2.4 \mathrm{mg} \mathrm{Cd} \mathrm{m}^{-1}$ and if breakdown of this regulatory ability will lead to toxic manifestations in the crab.

We have therefore conducted a series of experiments 
to examine the effect of cadmium on ion- and osmoregulatory processes in Carcinus maenas. We also wanted to investigate if the effects of cadmium on physiological processes could be attributed to accumulation and binding pattern of cadmium in the hemolymph.

\section{MATERIALS AND METHODS}

Adult male shore crabs Carcinus maenas (L.) were caught in seines in Little Belt, Denmark. The prehistory (concerning salinity) of the crabs was unknown since the salinity of Little Belt water may vary between 14 and $30 \%$, depending on depth and prevailing wind and stream (L. P. D. Rasmussen, pers. comm. 1985). Crabs used in February to April were caught in October and maintained in flowing seawater aquaria at the marine biological station Brgebjerg, N.E. Funen, Denmark. In the period May to September, freshly caught crabs were used. Prior to experiments the crabs were acclimated to experimental salinities and temperatures for $1 \mathrm{wk}$. Experimental salinities were made up by diluting Great Belt seawater (420 to $735 \mathrm{mOsm}$ ) with double distilled water. Little Belt and Great Belt seawater contains approximately $25 \mathrm{ng} \mathrm{Cd}$ $\mathrm{l}^{-1}$ (A. Jensen, pers, comm. 1985). The crabs were not fed during acclimation and experimental periods.

In 6 experimental series, groups of 4 to 6 crabs were exposed to cadmium (added as $\mathrm{CdCl}_{2} \cdot \mathrm{H}_{2} \mathrm{O}$ ) in $10 \mathrm{l}$ polystyrene aquaria containing aerated seawater. Hemolymph parameters were followed in the groups of crabs exposed to lethal cadmium concentrations as long as 3 crabs were still alive. In each experimental series 5 to 12 crabs ( 4 to 6 per aquarium) in uncontaminated seawater served as running control groups. Table 1 summarizes experimental conditions in the different experiments carried out.

During the exposure periods, $0.2 \mathrm{ml}$ hemolymph samples were drawn through the arthrodial membrane of the 4th periopod with hypodermic syringes. To prevent coagulation the hemolymph samples were immediately transferred to $0^{\circ} \mathrm{C}$ and maintained at this temperature until osmolality measurements and dilutions for cation determinations had taken place. The remaining parts of the hemolymph samples were stored at $-18^{\circ} \mathrm{C}$ for subsequent chloride determinations.

Osmolality was measured with a Knauer semimicro osmometer and sodium, potassium, calcium, magnesium, and cadmium were determined by atomic absorption spectroscopy (Beckmann 1248 \& PerkinElmer 2380). To eliminate interaction between the determination of individual ions, mixed standards with ion concentrations similar to crab hemolymph were employed. $\mathrm{La}_{2} \mathrm{O}_{3}$ was added to prevent phosphate interactions. Chloride determinations were performed with a Radiometer CMT 10 chloride titrator.

To investigate how cadmium was bound in the hemolymph, maximum obtainable hemolymph samples were drawn from the last surviving crab in the groups exposed to 6, 8, and $10 \mathrm{mg} \mathrm{Cd}^{-1}$ in Experiment 6. At Day 46 in the exposure, hemolymph samples were likewise drawn from the surviving crabs exposed

Table 1. Carcinus maenas. Summary of experimental conditions in the various experiments

\begin{tabular}{|c|c|c|c|c|c|c|c|c|c|c|c|c|c|c|}
\hline \multirow[t]{2}{*}{$\begin{array}{c}\text { Experi- } \\
\text { ment }\end{array}$} & \multirow[t]{2}{*}{$\begin{array}{l}\text { Date of } \\
\text { initiation }\end{array}$} & \multirow{2}{*}{$\begin{array}{c}\text { Exposure } \\
\text { conc. } \\
\left(\mathrm{mg} \mathrm{Cd} \mathrm{l}^{-1}\right)\end{array}$} & \multirow{2}{*}{$\begin{array}{l}\text { Osmo- } \\
\text { lality } \\
\text { (mOsm) }\end{array}$} & \multirow{2}{*}{$\begin{array}{l}\text { Tempe- } \\
\text { rature } \\
\left({ }^{\circ} \mathrm{C}\right)\end{array}$} & \multicolumn{2}{|c|}{ n } & \multicolumn{7}{|c|}{$\begin{array}{c}\text { Hemolymph parameters } \\
\text { determined }\end{array}$} & \multirow{2}{*}{$\begin{array}{l}\text { Median } \\
\text { survival } \\
\text { time (d) }\end{array}$} \\
\hline & & & & & group & group & Osm & $\mathrm{Na}$ & $\mathrm{Cl}$ & $\mathrm{K}$ & $\mathrm{Ca}$ & $\mathrm{Mg}$ & $\mathrm{Cd}$ & \\
\hline \multirow{3}{*}{1} & \multirow{3}{*}{$21 \mathrm{Mar}$} & 1 & $400 \pm 10$ & \multirow{3}{*}{$18 \pm 1$} & $5 \rightarrow 4$ & $5 \rightarrow 4$ & + & + & + & + & + & + & & $>22^{\mathrm{a}}$ \\
\hline & & 1 & $550 \pm 20$ & & $5 \rightarrow 5$ & $5 \rightarrow 5$ & + & + & + & + & + & + & & $>22^{d}$ \\
\hline & & 1 & $700 \pm 20$ & & $5 \rightarrow 5$ & $5 \rightarrow 5$ & + & + & + & + & + & + & & $>22^{a}$ \\
\hline \multirow{2}{*}{2} & \multirow{2}{*}{1 Jun } & 1 & \multirow{2}{*}{$400 \pm 10$} & \multirow{2}{*}{$15.5 \pm 0.5$} & $5 \rightarrow 4$ & \multirow{2}{*}{$8 \rightarrow 7$} & + & + & + & + & + & + & + & $>48^{a}$ \\
\hline & & 10 & & & 5 & & + & + & + & + & + & + & + & 11 \\
\hline 3 & $15 \mathrm{Feb}$ & 10 & $400 \pm 10$ & $15.5 \pm 0.5$ & 5 & $6 \rightarrow 6$ & + & + & + & + & + & + & + & 9 \\
\hline 4 & $15 \mathrm{May}$ & 10 & $400 \pm 10$ & $15.5 \pm 0.5$ & 5 & $10 \rightarrow 10$ & + & + & + & + & + & + & + & 9 \\
\hline 5 & 22 Aug & 10 & $400 \pm 10$ & $15.5 \pm 0.5$ & 6 & $12 \rightarrow 12$ & + & + & + & + & + & + & + & 7 \\
\hline \multirow{6}{*}{6} & \multirow{6}{*}{27 Aug } & 10 & \multirow{6}{*}{$400 \pm 10$} & \multirow{6}{*}{$15.5 \pm 0.5$} & 6 & \multirow{6}{*}{$12 \rightarrow 11$} & & & & & + & + & $t$ & 16 \\
\hline & & 8 & & & 6 & & & & & & + & + & + & 23 \\
\hline & & 6 & & & 6 & & & & & & + & + & + & 29 \\
\hline & & 4 & & & $6 \rightarrow 2$ & & & & & & + & + & + & 46 \\
\hline & & 2 & & & $6 \rightarrow 5$ & & & & & & + & + & $t$ & $>46^{\circ}$ \\
\hline & & 1 & & & $6 \rightarrow 6$ & & & & & & + & + & + & $>4 \hat{6}^{\mathrm{a}}$ \\
\hline
\end{tabular}


to 1,2 and $4 \mathrm{mg} \mathrm{Cd} \mathrm{l}^{-1}$. One $\mathrm{ml}$ hemolymph samples (pooled or from single crabs) were run through a $60 \mathrm{~cm} \times 0.9 \mathrm{~cm}$ Sephadex G-75 column. Twenty $\mathrm{mM}$ Tris $(\mathrm{pH}=8.1)$ was used as elution buffer and absorbance at $280 \mathrm{~nm}$ and cadmium content were determined in each fraction collected.

For an in vitro investigation of cadmium binding in the hemolymph, a pooled sample from 15 crabs was used. The protein concentration in the hemolymph was $53 \mathrm{~g} \mathrm{l}^{-1}$ (Biuret method; Bergmeyer 1974). Concentrations of $0.5,1,2,4,8,16,32,64,128$, and $256 \mu \mathrm{g} \mathrm{Cd} \mathrm{m}^{-1}$ were added to $0.5 \mathrm{ml}$ hemolymph samples, which were dialysed against $5.0 \mathrm{ml} \mathrm{crab}$ ringer $(360 \mathrm{mM} \mathrm{NaCl}$, $8 \mathrm{mM} \mathrm{KCl}, 22 \mathrm{mM} \mathrm{MgSO}$, $4 \mathrm{mM} \mathrm{NaHCO}, 10 \mathrm{mM}$ $\mathrm{CaCl}_{2}, \mathrm{pH}=8.0$ ) at $4{ }^{\circ} \mathrm{C}$. After 48 h the cadmium concentrations outside the dialysis bags were determined.

The statistical significance of differences between exposed groups and control groups were calculated using 2 -tailed Student $\mathrm{t}$-tests.

\section{RESULTS}

Crabs exposed to 1 and $2 \mathrm{mg} \mathrm{Cd} \mathrm{Cl}^{-1}$ did not show greater mortality than control groups (Table 1) Median survival times for crabs exposed to 4 to $10 \mathrm{mg}$ $\mathrm{Cd} \mathrm{l}^{-1}$ are shown in Table 1

Osmolality and ion concentrations in the crabs at Day 0 are shown in Table 2. Osmolality and $\mathrm{Na}^{+}$and $\mathrm{Cl}^{-}$concentrations in crabs acclimated to $400 \mathrm{mOsm}$ were lower in crabs kept at the field station during autumn and winter than in freshly caught crabs Osmolality and $\mathrm{Na}^{+}$and $\mathrm{Cl}^{-}$concentrations in the control crabs decreased slightly during experimental periods, while $\mathrm{K}^{+}, \mathrm{Ca}^{++}$, and $\mathrm{Mg}^{++}$levels showed no consistent changes.

\section{Experiment 1}

Crabs exposed to $1 \mathrm{mg} \mathrm{Cd}^{-1}$ at 400 to 700 mOsm (14 to $24 \%$ ) for $22 \mathrm{~d}$ showed no changes in hemolymph osmolality and $\mathrm{Na}^{+}, \mathrm{Cl}^{-}, \mathrm{K}^{+}, \mathrm{Ca}^{++}$, and $\mathrm{Mg}^{++}$levels relative to control groups (data not shown).

\section{Experiments 2 to 5}

Crabs exposed to $1 \mathrm{mg} \mathrm{Cd} \mathrm{l}^{-1}$ at $400 \mathrm{mOsm}$ for $48 \mathrm{~d}$ (Exp. 2) showed no changes in hemolymph osmolality and $\mathrm{Na}^{+}, \mathrm{Cl}^{-}, \mathrm{K}^{+}, \mathrm{Ca}^{++}$, and $\mathrm{Mg}^{++}$concentrations relative to the control group (data not shown). The

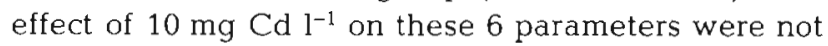
consistent in the 6 experiments (Fig. 1). In May and August exposure to $10 \mathrm{mg} \mathrm{Cd} \mathrm{l}^{-1}$ produced significant increases in hemolymph $\mathrm{Na}^{+}$levels, and the same trend was seen in June. Increases were most pronounced after 2 to $4 \mathrm{~d}$, after which a decline towards control levels was observed. Osmolality and $\mathrm{Cl}^{-}$levels showed significant increases after $4 \mathrm{~d}$ exposure in the August experiment only. In the May experiment osmolality tended to increase. In the June experiment osmolality and $\mathrm{Cl}^{-}$and $\mathrm{K}^{+}$concentrations tended to decrease after $8 \mathrm{~d}$ exposure. $\mathrm{K}^{+}$showed a significant increase after $4 \mathrm{~d}$ exposure in May and magnesium levels either showed an initial decrease (Feb and Jun) or they remained unaffected. Calcium levels rose to 160 to $180 \%$ of controls after 7 to $8 \mathrm{~d}$ exposure to $10 \mathrm{mg}$ $\mathrm{Cd} \mathrm{l}^{-1}$ in May, June, and August, while $5 \mathrm{~d}$ exposure did not affect calcium levels in February. The effect of cadmium on calcium levels appeared faster in August than in May and June.

In May, June, and August crabs exposed to $10 \mathrm{mg}$ $\mathrm{Cd}^{-1}$ reached cadmium levels in the hemolymph of 20

Table 2. Carcinus maenas. Hemolymph osmolality and inorganic ion concentrations (mean $\pm \mathrm{SD}$ ) in crabs at Day 0 in each experiment

\begin{tabular}{|c|c|c|c|c|c|c|c|}
\hline $\begin{array}{l}\text { Experi- } \\
\text { ment }\end{array}$ & Date & $\begin{array}{l}\text { Osmolality } \\
\text { (mOsm) }\end{array}$ & $\begin{array}{l}\mathrm{Na}^{+} \\
(\mathrm{mM})\end{array}$ & $\begin{array}{l}\mathrm{Cl}^{-} \\
(\mathrm{mM})\end{array}$ & $\begin{array}{c}\mathrm{K}^{+} \\
(\mathrm{mM})\end{array}$ & $\begin{array}{l}\mathrm{Ca}^{++} \\
(\mathrm{mM})\end{array}$ & $\begin{array}{l}\mathrm{Mg}^{++} \\
(\mathrm{mM})\end{array}$ \\
\hline 1 & $21 \mathrm{Mar}$ & $\begin{array}{l}649 \pm 18 \\
726 \pm 5^{a} \\
795 \pm 5^{b}\end{array}$ & $\begin{array}{l}301 \pm 24 \\
351 \pm 18 \\
376 \pm 12\end{array}$ & $\begin{array}{l}326 \times 21 \\
370 \pm 11 \\
399 \pm 14\end{array}$ & $\begin{array}{l}8.1 \pm 0.5 \\
8.7 \pm 1.0 \\
8.7 \pm 0.5\end{array}$ & $\begin{array}{l}7.8 \pm 0.9 \\
8.9 \pm 1.1 \\
9.9 \pm 0.4\end{array}$ & $\begin{array}{l}10.0 \pm 1.5 \\
12.0 \pm 1.0 \\
15.0 \pm 2.0\end{array}$ \\
\hline 2 & 1 Jun & $694 \pm 40$ & $361 \pm 10$ & $366 \pm 30$ & $8.2 \pm 0.6$ & $7.8 \pm 0.6$ & $11.7 \pm 0.8$ \\
\hline 3 & 15 Feb & $620 \pm 35$ & $310 \pm 15$ & $313 \pm 27$ & $8.2 \pm 0.9$ & $7.1 \pm 0.4$ & $9.2 \pm 1.1$ \\
\hline 4 & 15 May & $765 \pm 23$ & $384 \pm 14$ & $383 \pm 22$ & $8.3 \pm 0.2$ & $8.8 \pm 1.0$ & $11.3 \pm 1.0$ \\
\hline 5 & $22 \mathrm{Aug}$ & $735 \pm 36$ & $349 \pm 15$ & $321 \pm 32$ & $8.5 \pm 0.6$ & $7.7 \pm 0.8$ & $10.4 \pm 1.4$ \\
\hline 6 & $27 \mathrm{Aug}$ & nd & nd & nd & nd & $8.1 \pm 1.1$ & $11.1 \pm 1.0$ \\
\hline
\end{tabular}




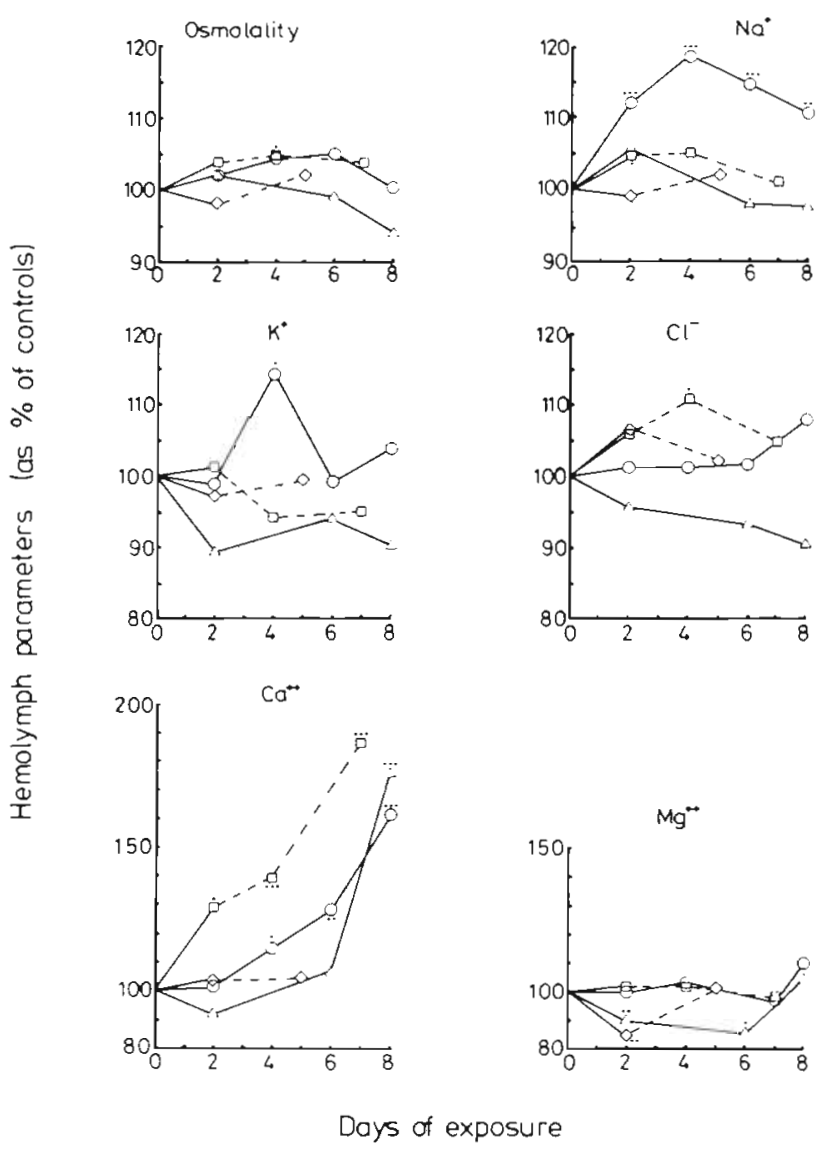

Fig. 1. Carcinus maenas. Hemolymph parameters in crabs

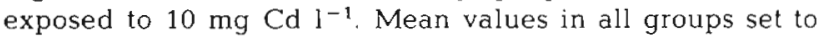
$100 \%$ at Day 0. Parameters in exposed groups are expressed relative to values in control group during experiments. ( $\Delta) 1$ $J_{u n}(\square) 22$ Aug; ( $(0) 15$ Feb; (O) 15 May. Broken lines indicate death of 1 or several exposed crabs between sampling times. Numbers of specimens given in Table $1 .(\bullet),(\bullet)$, and ( $\bullet \bullet)$ indicate differences from the control group at $5 \%, 1 \%$, and $0.1 \%$ level, respectively

to $32 \mu \mathrm{g} \mathrm{Cd} \mathrm{ml} \mathrm{m}^{-1}$ in 7 to $8 \mathrm{~d}$, while uptake rates in February were lower (Fig. 2b). Crabs exposed to $1 \mathrm{mg}$ $\mathrm{Cd} \mathrm{l}^{-1}$ (Jun) reached a hemolymph cadmium level of approximately $0.8 \mu \mathrm{g} \mathrm{Cd} \mathrm{ml}^{-1}$ within $1 \mathrm{wk}$ and no further increase appeared during 48 d exposure (Fig. 2a).

\section{Experiment 6}

Cadmium levels in the hemolymph of crabs exposed to $1,2,4,6,8$, and $10 \mathrm{mg} \mathrm{Cd} \mathrm{C}^{-1}$ are shown in Fig. 3a. Crabs exposed to 1 and $2 \mathrm{mg} \mathrm{Cd} \mathrm{Cl}^{-1}$ approached the ambient cadmium concentration in the first week and during $44 \mathrm{~d}$ exposure the cadmium concentrations in the hemolymph remained at or slightly below ambient

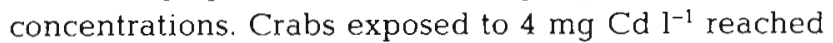
levels of 8 to $10 \mu \mathrm{g} \mathrm{Cd} \mathrm{ml} \mathrm{m}^{-1}$ hemolymph after about

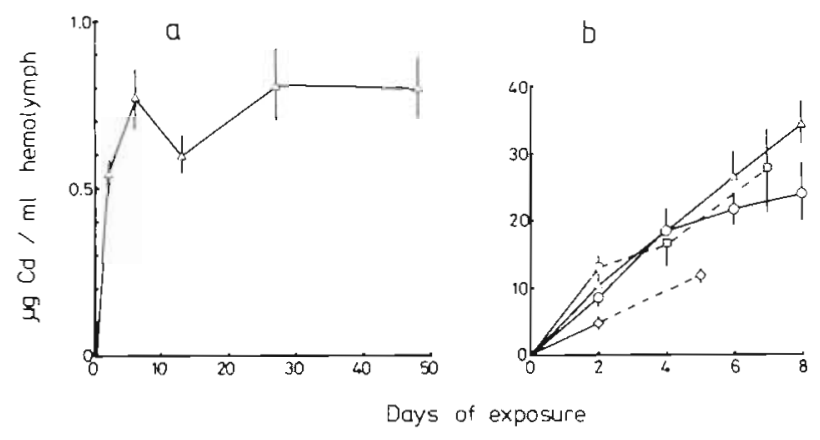

Fig. 2. Carcinus maenas. Hemolymph cadmium concentra-

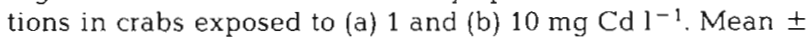

SEM. For explanation of symbols, see legend to Fig. 1

$2 w k$, and no further increase was seen. Cadmium concentrations in the hemolymph of crabs exposed to

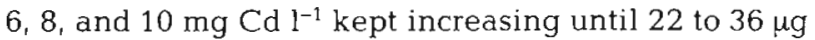
$\mathrm{Cd} \mathrm{ml}^{-1}$ where death occured.

Calcium levels in crabs exposed to cadmium con-

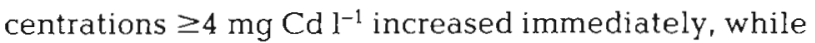
calcium levels in crabs exposed to $1 \mathrm{mg} \mathrm{Cd}^{-1}$ remained unaffected (Fig. 3b). Two $\mathrm{mg} \mathrm{Cd} \mathrm{l}^{-1}$ seemed to cause an increase in calcium levels after prolonged exposure (Fig. 3b).

Magnesium levels in the hemolymph were not

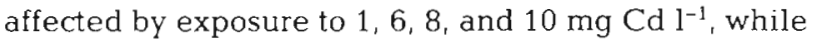
2 and $4 \mathrm{mg} \mathrm{Cd}^{-1}$ caused significant reductions in magnesium levels (Fig. 3c). After $44 \mathrm{~d}$ exposure the magnesium concentration in the group exposed to $4 \mathrm{mg} \mathrm{Cd}^{-1}$ was only $44 \%$ of that in the control group.

Fig. 4 shows Sepadex G-75 elution profiles for hemolymph from crabs exposed to 1, 4, and $10 \mathrm{mg}$ $\mathrm{Cd} \mathrm{l}^{-1}$. Recovery of hemolymph cadmium after gel filtration varied between 88 and $102 \%$. Cadmiurn was bound in the high molecular weight fraction and little cadmium enrichment was observed in the low molecular weight fraction.

\section{In vitro experiment}

When $0.5,1,2,4$, and $8 \mu \mathrm{g} \mathrm{Cd}$ was added per ml hemolymph in vitro, the concentrations of dialysable cadmium were below the detection limit $(\approx 50$ ng free $\mathrm{Cd}[\mathrm{ml} \text { hemolymph }]^{-1}$ ). The concentrations of dialysable cadmium in the hemolymph after addition of 16 ,

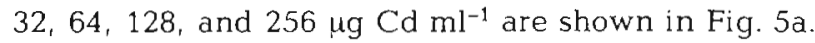
After addition of $16 \mu \mathrm{g} \mathrm{Cd} \mathrm{ml} l^{-1}, 0.19 \mu \mathrm{g} \mathrm{Cd} \mathrm{ml}^{-1}$ is dialysable and the increase in dialysable cadmium for higher amounts of cadmium added show complex kinetics (in between linear and exponential increase). The number of cadmium ions bound to each hemocyanin molecule increases rapidly for low concentrations of free $\mathrm{Cd}^{++}$(Fig. 5b). The number of cadmium ions 

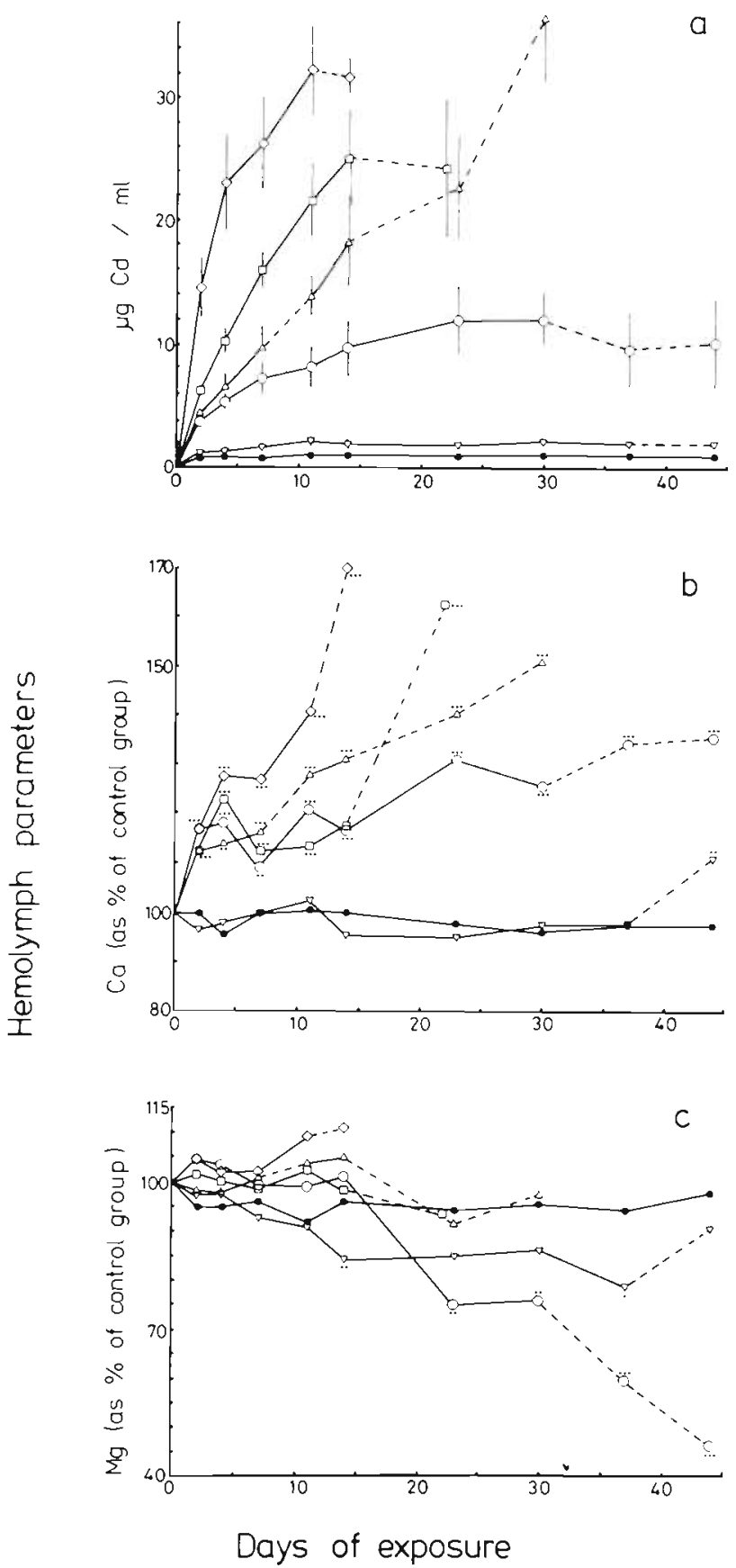

Fig. 3. Carcinus maenas. Hemolymph (a) cadmium, (b) calcium, and (c) magnesium concentrations in crabs exposed to (•) $1,(\nabla) 2,(0) 4,(\Delta) 6$, (口) 8 , and $(\diamond) 10 \mathrm{mg} \mathrm{Cd} \mathrm{l}^{-1}$. Broken lines indicate death of 1 or several crabs between sampling times. Symbols in (a) represent mean \pm SEM. (b) and (c) expressed as explained in legend to Fig. 1

bound to each hemocyanin molecule seems to be determined by saturation kinetics, although saturation of hemocyanin with cadmium was not achieved. The hemocyanin concentration. was calculated from the total protein content in the hemolymph (approximately $95 \%$ hemocyanin, $\mathrm{MW}=75000$; Zatta 1984).

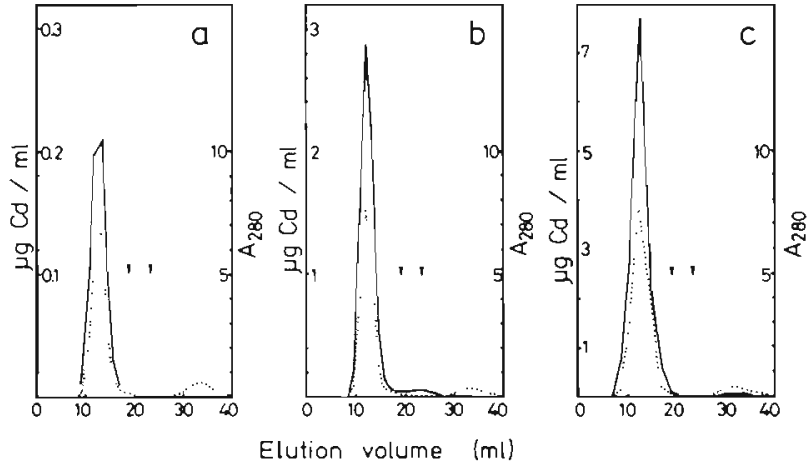

Fig. 4. Carcinus maenas. Sephadex G-75 elution profiles for hemolymph from crabs exposed to: (a) $1 \mathrm{mg} \mathrm{Cd}^{-1}$ for $46 \mathrm{~d}$

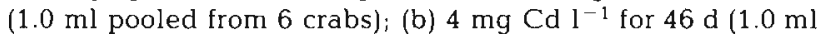
pooled from $2 \mathrm{crabs})$, and (c) $10 \mathrm{mg} \mathrm{Cd} \mathrm{l}^{-1}$ for $17 \mathrm{~d}(1.0 \mathrm{ml}$ from $1 \mathrm{crab}$ ). Dotted lines: $\mathrm{A}_{280}$; solid lines: $\mathrm{Cd}$. Detection limit for

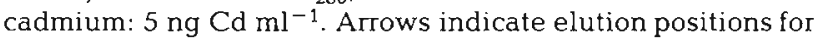
chymotrypsinogen $\mathrm{A}(\mathrm{MW}=25000)$ and cytochrome c (MW $=12500)$
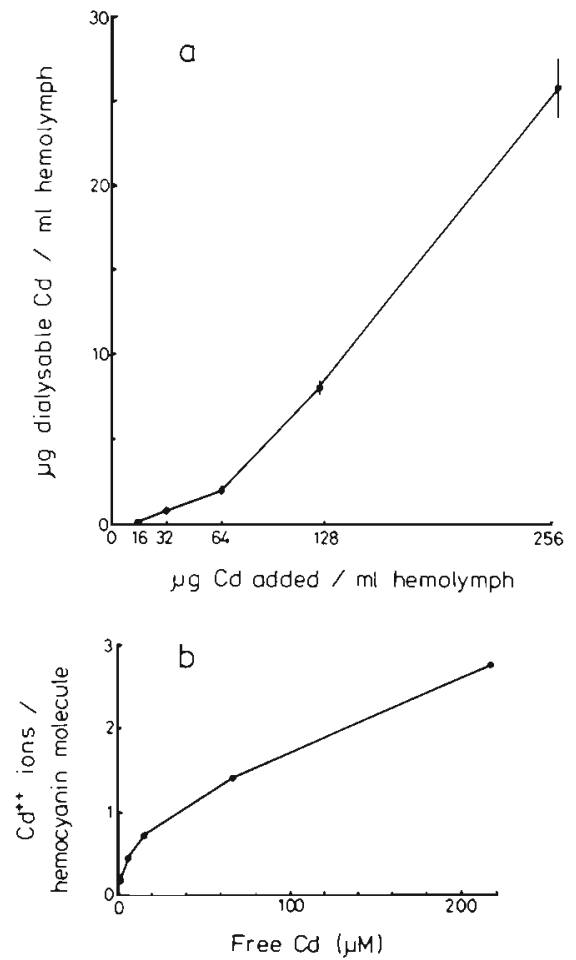

Fig. 5. Carcinus maenas. (a) Partition of cadmium between dialysable and non-dialysable fraction after in vitro addition of cadmium to crab hemolymph. Mean \pm SEM for 2 determinations. (b) Number of cadmium ions bound to each hemocyanin molecule as a function of the concentration of free cadmium ions. Calculated from means in Fig. 5a

\section{DISCUSSION}

In the present study $1 \mathrm{mg} \mathrm{Cd}^{-1}$ (at 400 mOsm and $18^{\circ} \mathrm{C}$ ) was not lethal in $22 \mathrm{~d}$. Wright $(1977 \mathrm{a})$ likewise found that $2.4 \mathrm{mg} \mathrm{Cd}^{-1}$ (at $500 \mathrm{mOsm}$ and $10^{\circ} \mathrm{C}$ ) was not lethal in $68 \mathrm{~d}$, while Thurberg et al. (1973) found 
that $1 \mathrm{mg} \mathrm{Cd} \mathrm{l}^{-1}$ (at $450 \mathrm{mOsm}$ and 19 to $22{ }^{\circ} \mathrm{C}$ ) was lethal in $48 \mathrm{~h}$. Furthermore, Thurberg et al. (1973) observed increases (maximally $7 \%$ ) in hemolymph osmolalities in crabs exposed to $0.5,1,2,4$, and $8 \mathrm{mg}$ $\mathrm{Cd} \mathrm{l}^{-1}$ at $450,600,700,800$, and $900 \mathrm{mOsm}$ for $48 \mathrm{~h}$, while in the present study exposure to $1 \mathrm{mg} \mathrm{Cd} \mathrm{l}^{-1}$ caused no effect on hemolymph osmolalities at $18^{\circ} \mathrm{C}$ and 400, 550 and $700 \mathrm{mOsm}$. However, the crabs of Thurberg et al. (1973) had been acclimated to 700 mOsm, and then simultaneously exposed to changed salinity and cadmium. Crabs not in osmotic equilibrium may be more sensitive to cadmium both with respect to mortality and effects on osmoregulation than crabs in osmotic equilibrium. Also, the variation in temperature between the 2 studies may explain the different results.

The small increase in osmolality in crabs exposed to

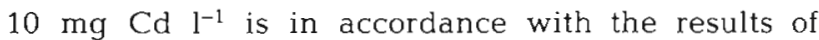
Thurberg et al. (1973). Quantitatively, $\mathrm{Na}^{+}$and $\mathrm{Cl}^{-}$are the most important inorganic ions in crab hemolymph and therefore changes in osmolality would be expected to be caused by changes in $\mathrm{Na}^{+}$and/or $\mathrm{Cl}^{-}$ concentrations. This is observed in most experiments (Fig. 1), but it is noteworthy that the pronounced increase in $\mathrm{Na}^{+}$concentrations in the May experiment is followed only by slight (and not significant) increase in osmolalities. The variation between individual experiments of the effects of $10 \mathrm{mg} \mathrm{Cd} \mathrm{l}^{-1}$ on osmolality and $\mathrm{Na}^{+}, \mathrm{Cl}^{-}$, and $\mathrm{K}^{+}$concentrations could not clearly be attributed to dependence on time of year and thereby stage in the moult cycle.

The effects of prolonged cadmium exposure on magnesium regulation show a complex concentration dependence, since only 2 and $4 \mathrm{mg} \mathrm{Cd} \mathrm{^{-1 }}$, but not 1,6 , 8 , and $10 \mathrm{mg} \mathrm{Cd} 1^{-1}$, reduce hemolymph magnesium levels (Fig. 3c). Prolonged exposure to copper concen-

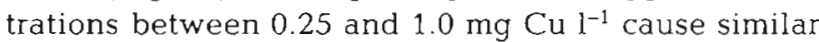
reductions in magnesium concentrations in Carcinus maenas (Bjerregaard \& Vislie 1985a). C. maenas normally maintains low hemolymph magnesium concentrations relative to ambient seawater by excreting magnesium via the antennal gland-bladder complex (Lockwood \& Riegel 1969, Zanders 1980b). Cadmium may reduce hemolymph magnesium levels by: (1) altering gill permeability for magnesium, (2) augmenting urine production rates, or (3) stimulating magnesium secretion in the bladder, but the present data do not indicate which mechanism is the most probable one.

Exposure to cadmium concentrations $\geq 4 \mathrm{mg} \mathrm{Cd} \mathrm{I}^{-1}$ augmented hemolymph calcium levels. Wright (1977c) found an augmenting effect on hemolymph calcium levels of $2.4 \mathrm{mg} \mathrm{Cd}^{-1}$ after $6 \mathrm{~d}$ in postmoult crabs, but not in intermoult crabs.

Cadmium could augment hemolymph calcium levels by: (1) stimulating calcium transport over the gills from seawater to hemolymph, (2) inducing release of calcium from calcium-containing organs (exoskeleton and hepatopancreas) to the hemolymph, (3) interfering with the hormonal regulation of moulting and thereby calcium metabolism (Robertson 1937, 1960), or (4) diminishing urine production rates.

In the freshwater amphipod Gammarus pulex, 0.6 $\mathrm{mg} \mathrm{Cd} \mathrm{\textrm {I } ^ { - 1 }}$ reduce calcium uptake (Wright 1980 ) and the activity of the $\mathrm{Ca}^{2+}$ ATPase extracted from gills of roach Rutilus rutilus are inhibited in vitro by heavy metals (Shephard \& Simkiss 1978). It is thus unlikely that cadmium should stimulate calcium uptake via the gills in Carinus maenas.

As for the second possibility, Roer (1980) has shown that active transport of calcium across the hypodermis takes place by means of a Ca-ATPase and a Na/Ca exchange mechanism. If cadmium inhibits active transport of calcium from hemolymph to exoskeleton, hemolymph calcium levels would increase due to passive influx of calcium from the exoskeleton (Roer 1980). Cadmium could then reduce active calcium transport either directly by inhibiting the Ca-ATPase or indirectly by inhibiting the ouäbäin sensitive $\mathrm{Na}^{+}$ transport and thereby the $\mathrm{Na} / \mathrm{Ca}$ exhange pump. Transport of calcium from the hemolymph to the exoskeleton is approximately 8 times higher in postmoult crabs than in intermoult crabs (Roer 1980). This may explain why Wright (1977c) found an effect of cadmium on calcium regulation in postmoult crabs, but not in intermoult crabs. Adult male crabs in Danish waters moult in June to July (Rasmussen 1973) and in the present study effects of $10 \mathrm{mg} \mathrm{Cd} \mathrm{l}^{-1}$ on hemolymph calcium levels tend to appear faster in the August experiment (late postmoult) than in May and June (premoult).

The effect of cadmium on hemolymph calcium levels resembles that caused by injecting moult-promoting hormone from the Y-organ (Carlisle 1957). In the intermoult stage secretion of the moult-promoting hormone is inhibited by the moult-inhibiting hormone - a polypetide - produced in the X-organ-sinus gland complex (Carlisle 1957). If cadmium affects the production or function of the moult-inhibiting hormone, the observed changes in calcium levels would be expected in association with the partial resorption of the exoskeleton initiating the moult processes (Robertson 1937, Roer 1980). However, this hypothesis cannot explain why Wright $(1977 \mathrm{C})$ found an effect of cadmium on calcium levels in postmoult but not in intermoult crabs.

Toxic concentrations of copper and mercury also augment hemolymph calcium levels in Carcinus anaenas (Bjerregaard \& Vislie 1985a, b) and the interactions of heavy metals with the complex calcium metabolism of $C$. maenas bear further investigations. 
It is in accordance with the observations of Wright (1977a, b) and Wright \& Brewer (1979) that Carcinus maenas exposed to $\leqslant 2 \mathrm{mg} \mathrm{Cd} \mathrm{l}^{-1}$ maintain hemolymph cadmium concentrations at or slightly below ambient concentrations. Crabs exposed to $\geqslant 4 \mathrm{mg} \mathrm{Cd} \mathrm{l}^{-1}$ concentrate cadmium in the hemolymph to concentrations that are higher than ambient cadmium concentrations and $C$. maenas does not seem to be able to survive with hemolymph cadmium concentrations that are higher than 35 to $40 \mu \mathrm{g} \mathrm{Cd} \mathrm{ml}^{-1}$. It is noteworthy that at these hemolymph cadmium concentrations, substantial amounts of free cadmium start to appear in the hemolymph. Likewise, the effect of cadmium on hemolymph calcium levels also seems to be related to the hemolymph cadmium concentration (Fig. 3a, b).

Jennings et al. (1979) and Rainbow \& Scott (1979) demonstrated 2 proteins ( $M W=12500$ and 27000 ) in Carcinus maenas with a high affinity for cadmium. Jennings et al. (1979) suggest that cadmium entering the hemolymph via the gills is transported to other organs - mainly hepatopancreas - bound to low molecular weight proteins. The present study, however, shows that the major part of the cadmium present in the hemolymph is bound in the high molecular weight fraction - probably to hemocyanin, which constitutes more than $95 \%$ of the protein in crab hemolymph (Uglow 1969, Zatta 1984). Likewise, Zatta (1984) - based on the metabolism of zinc in C. maenas - suggests that hemocyanin can act as a metal carrier in the hemolymph. Wright \& Brewer's (1979) results indicate that the turnover time for hemolymph cadmium is relatively short (approximately $50 \%$ of the cadmium exchanged in $40 \mathrm{~h}$ ) and Zatta (1984) found similar values for zinc. Thus, with the very limited amount of cadmium bound in the low molecular weight fraction it does not seem likely that this fraction could act as the most important vector for cadmium transport in the hemolymph, although the turnover time for cadmium in this fraction may be very fast. However, the mechanism for regulation and transport of cadmium in the hemolymph of $C$. maenas needs further clarifying.

Acknowledgements. We thank René Støvring for technical assistance.

\section{LITERATURE CITED}

Bergmeyer, H. V. (1974). Methods of enzymatic analysis. Verlag Chemie, Weinheim/Academic Press, New York \& London

Bjerregaard, P. (1982). Accumulation of cadmium and selenium and their mutual interaction in the shore crab Carcinus maenas (L.). Aquat. Toxicol. 2: 113-125

Bjerregaard, P., Vislie, T (1985a). Effects of copper on ionand osmoregulation in the shore crab Carcinus maenas (L.). Mar. Biol. (in press)
Bjerregaard, P., Vislie, T. (1985b). Effects of mercury on jonand osmoregulation in the shore crab Carcinus maenas (L.) Comp. Biochem. Physiol. C (in press)

Carlisle, D. B. (1957). On the hormonal inhibition of moulting in decapod crustacea. II. The terminal anecdysis in crabs. J. mar biol. Ass. U. K. 36: 291-307

Chassard-Bouchaud, C. (1982). Ultrastructural study of cadmium concentration by the digestive gland of the crab Carcinus maenus (Crustacea Decapoda). Electron probe X-ray microanalysis. C. R. Séanc. Acad. Sci. Ser. III. 294: $153-158$

Coombs, T L. (1979). Cadmium in aquatic organisms. In: Webb, M. (ed.). The chemistry, biochemistry and biology of cadmium. Elsevier/North Holland Biomedical Press, Amsterdam, New York \& Oxford, p. 93-139

Greenaway, P. (1976). The regulation of haemolymph calcium concentration of the crab Carcinus maenas (L.). J. exp. Biol. 64: 149-157

Hutcheson, M. S. (1974). The effect of temperature and salinity on cadmium uptake by the blue crab Callinectes sapidus. Chesapeake Sci. 15: 237-241

Jennings, J. R., Rainbow, P. S. (1979). Studies on the uptake of cadmium by the crab Carcinus maenas in the laboratory. I. Accumulation from seawater and a food source. Mar. Biol. 50: 131-139

Jennings, J. R., Rainbow, P. S., Scott, A. G. (1979). Studies on the uptake of cadmium by the crab Carcinus maenas in the laboratory. II. Preliminary investigation of cadmiumbinding proteins. Mar. Biol. 50: 141-149

Lockwood, A. P. M., Riegel, J. A. (1969). The excretion of magnesium by Carcinus maenas. J. exp. Biol. 51: 575-589

O'Hara, J. (1973a). Cadmium uptake by fiddler crabs exposed to temperature and salinity stress. J. Fish. Res. Bd Can. 30: $846-848$

O'Hara, J. (1973b). The influence of temperature and salinity on the toxicity of cadmium to the fiddler crab Uca pugilator. Fish. Bull. Fish Wildl. Serv. U. S. 71: 149-153

Rainbow, P. S., Scott, A. G. (1979). Two heavy metal-binding proteins in the midgut gland of the crab Carcinus maenas. Mar. Biol. 55: 143-150

Rasmussen, E. (1973). Systematics and ecology of the Isefjord marine fauna (Denmark). Ophelia 11: 1-507

Robertson, J. D. (1937). Some features of the calcium metabolism of the shore crab (Carcinus maenas Pennant). Proc. R. Soc. B. 124: 162-182

Robertson, J. D. (1960). Ionic regulation in the crab Carcinus maenas (L.) in relation to the moulting cycle. Comp. Biochem. Physiol. 1: 183-212

Roer, R. D. (1980). Mechanisms of resorption and deposition of calcium in the carapace of the crab Carcinus meanas. J. exp. Biol. 88: 205-218

Rosenberg, R., Costlow, J. D., Jr. (1976). Synergistic effects of cadmium and salinity combined with constant and cycling temperatures on the larval development of two estuarine crab species. Mar. Biol. 38: 291-303

Shephard, K., Simkiss, K. (1978). The effects of heavy metal ions on $\mathrm{Ca}^{2+}$ ATPase extracted from fish gills. Comp. Biochem. Physiol. 61B: 69-72

Shaw, J. (1961). Studies on ionic regulation in Carcinus maenas (L.). I. Sodium balance. J. exp. Biol. 38: 135-152

Theede, H. (1969). Einige neue Aspekte bei der Osmoregulation von Carcinus maenas. Mar. Biol. 2: 114-120

Thurberg, F. P., Dawson, M. A., Collier, R. S. (1973). Effects of copper and cadmium on osmoregulation and oxygen consumption in two species of estuarine crabs. Mar. Biol. 23: 171-175

Uglow, R. F. (1969). Haemolymph protein concentrations in 
portunid crabs. I. Studies on adult Carcinus maenas. Comp. Biochem. Physiol. 30: 1083-1090

Webb, D. A. (1940). Ionic regulation in Carcinus maenas. Proc. R. Soc. B. 129: 107-137

Wright, D. A. (1977a). The effect of salinity on cadmium uptake by the tissues of the shore crab Carcinus maenas. J. exp. Biol. 67: 137-146

Wright, D. A. (1977b). The uptake of cadmium into the haemolymph of the shore crab Carcinus maenas: the relationship with copper and other divalent cations. J. exp Biol. 67: 147-161

Wright, D. A. (1977c). The effect of calcium on cadmium uptake by the shore crab Carcinus maenas. J. exp. Biol. 67: $163-173$
Wright, D. A., Brewer, C. C. (1979). Cadmium turnover in the shore crab Carcinus maenas. Mar Biol 50: 151-156

Wright, D. A. (1980). Cadmium and calcium interactions in the freshwater amphipod Gammarus pulex. Freshwat. Biol. 10: 123-133

Zanders, I. P. (1980a). Regulation of blood ions in Carcinus maenas (L.). Comp. Biochem. Physiol. 65A: 97-108

Zanders, I. P. (1980b). The control of magnesium and sulphate excretion in Carcinus maenas (L.). Comp. Biochem. Physiol. 66 A: $69-76$

Zatta, P. (1984). Zinc transport in the haemolymph of Carcinus maenas (Crustacea: Decapoda). J mar. biol. Ass. U. K. 64 : 801-807

This paper was submitted to the editor; it was accepted for printing on September 9, 1985 